Date of Publication: 24/10/2012

\section{Cunninghamia}

A journal of plant ecology for eastern Australia
\&Domain Trust

ISSN $0727-9620$ (print) • ISSN 2200-405X (Online)

\title{
Vegetation structure and floristics of granite landforms in the South-west Slopes of New South Wales
}

\author{
Damian R. Michael* and David B. Lindenmayer \\ Fenner School of Environment and Society, The Australian National University, Canberra, ACT. 0200 AUSTRALIA. \\ *Corresponding author: damian.michael@anu.edu.au
}

\begin{abstract}
We describe the natural vegetation structure and floristics of 44 small-sized granite outcrops (inselbergs) in agricultural landscapes in the South-west Slopes (SWS) bioregion of New South Wales (35 $26^{\prime}$ S, $147^{\circ} 23^{\prime}$ E to $\left.35^{\circ} 58^{\prime} \mathrm{S}, 146^{\circ} 59^{\prime} \mathrm{E}\right)$ and their relationships with geomorphology. We provide a list of 196 species (117 natives and 79 exotics). We found that structurally complex outcrops supported a greater diversity of native ground cover species and fewer exotic species than structurally simple outcrops. Tor landforms lacked vegetation structural complexity and were deficient in native shrubs, mid-storey and over-storey species but typically supported exotic grasses and broadleaved exotic weeds. Floristic composition differed among landforms and cluster analysis revealed highly dissimilar native plant communities among outcrops. Our study highlights the need to rehabilitate tor landforms and manage a broad spectrum of outcrops to conserve floristic diversity in agricultural landscapes. Selecting genetically diverse species for replanting, considering the density and spatial arrangement of plantings, and controlling invasive plants and feral herbivorous animals are fundamental issues in restoring granite outcrop vegetation in the SWS bioregion.
\end{abstract}

Cunninghamia (2012) 12 (4):309-323

doi: 10.7751/cunninghamia.2012.12.022

\section{Introduction}

Inselbergs are granite outcrops that rise abruptly from flat landscapes (Twidale 1982) providing a broad range of micro-climatic conditions that contrast with surrounding landscapes (Campbell 1997) and supporting biologically diverse communities (Porembski \& Barthlott 2000). For these reasons, the biota of inselbergs have fascinated scientists from around the world for over 200 years (Walters 1982), not least because these environs are rich in endemic taxa (Porembski \& Barthlott 2000), but also because they provide a model framework for examining patterns of floristic diversity and species composition in the context of island biogeography theory (Burke 2003, Butler \& Fensham
2008, Michael et al. 2008). However, in many parts of the world, agricultural development and the associated impacts of habitat fragmentation is threatening the natural insularity of inselbergs by creating smaller habitat isolates, and increasing isolation by reduced vegetation connectivity. This process has serious implications for the long-term viability of plant populations in modified landscapes (Broadhurst \& Young 2006, Broadhurst et al. 2008).

An important aspect of inselberg ecology is their role in providing refugia for endemic and fire sensitive flora. Fires on granite outcrops are generally rare due to the buffering effect of rock (Burke 2003), and in the absence of fire, fire-sensitive and mesic-adapted plants such as ferns grow in sheltered locations (Hopper et al. 1997). Many outcrops 
support obligate seeders (Hopper 2000, Hunter 2003) such as Callitris spp., Acacia spp., Pultenaea spp. and Dodonaea spp. which germinate following fire, in contrast to sprouters which regenerate primarily from epicormic buds or underground rhizomes, such as many Eucalyptus spieces (Clarke 2002). In sclerophyllous vegetation, frequent high-intensity fires promote sprouters whereas intermediate low-intensity fires promote obligate seeders (Keith 1996). Frequent fires can therefore alter plant species composition, a process which can threaten the integrity and long-term persistence of outcrop flora (Bradstock et al. 2002).

The grassy box woodlands of temperate south-eastern Australia represent a broad bio-climatic region that has been extensively modified (Beadle 1981) and continues to be threatened by agricultural intensification and urban development (Yates \& Hobbs 1997, Lindenmayer et al. 2010). It is estimated that less than $5 \%$ of the original grassy box woodland remains intact (Prober 1996), with much of the remaining vegetation occurring on skeletal soils and rocky outcrops. The South-west Slopes (SWS) botanical region of New South Wales is one of the most heavily cleared bioregions in New South Wales (Benson 2008). Grassy box woodlands are significantly fragmented; improvements to the condition and extent of remnant vegetation are a priority conservation action of natural resource management agencies (Murray Catchment Management Authority 2007). If it were not for an archipelago of rocky outcrops in the SWS, the majority of which are granite, grassy box woodland may have been more extensively cleared than current vegetation patterns suggest.

In Western Australia, inselberg vegetation has been the subject of considerable research (Smith 1962, Burgman 1987, Ornduff 1987, Hopper et al. 1997, Ohlemuller 1997, Porembski et al. 1997, Pigott 2000, Porembski 2000), whereas inselbergs in eastern Australia have received far less attention (Ashton \& Webb 1977, Norris \& Thomas 1991, Hunter \& Clarke 1998). The value of granite outcrops in supporting rock-dwelling reptiles in agricultural landscapes has been reported recently in the SWS (Michael et al. 2008, Michael et al. 2010a), and specific management actions have been proposed to enhance habitat for this group (Michael et al. 2010b). Given the paucity of vegetation studies in the SWS (Burrows 1999), additional studies are required which may help inform restoration activities in the region. The main aim of this study was to examine vegetation patterns and floristic composition of relatively small granite outcrops in relation to different landforms. It is widely recognized that vegetation communities change in response to lithology (Norris \& Thomas 1991, Burrows 1999). However, the influence of geological landform on patterns of vegetation is less well understood (Kruckenburg 2002). We frame our study by proposing three main questions. 1) Do current patterns of vegetation structure differ among landforms of the same geology? 2) Is floristic composition influenced by granite landform? 3) Can these findings help guide conservation and restoration activities in the SWS bioregion?

\section{Methods}

\section{Study area}

This study area was in the southern half of the South-west Slopes (SWS) bioregion of New South Wales, bordered by Big Springs in the north ( $\left.35^{\circ} 19^{\prime} \mathrm{S}, 147^{\circ} 25^{\prime} \mathrm{E}\right)$, Albury in the south ( $\left.36^{\circ} 00^{\prime} \mathrm{S}, 146^{\circ} 53^{\prime} \mathrm{E}\right)$, Kyeamba in the east $\left(35^{\circ}\right.$

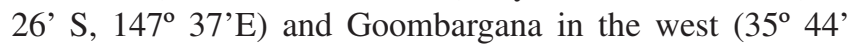
$\left.\mathrm{S}, 146^{\circ} 34^{\prime} \mathrm{E}\right)$. Annual average rainfall in the region ranges from approximately $450 \mathrm{~mm}$ at Walbundrie to $550 \mathrm{~mm}$ near Tarcutta (Bureau of Meterology 2012). Due to drought conditions the average monthly precipitation during the study period, Oct 2006 - Feb 2007, was generally below average for each month (2006 Oct- $2.4 \mathrm{~mm}$, Nov- $46.2 \mathrm{~mm}$, Dec- 1.6 mm; 2007 Jan- 36.5 mm, Feb- 40.8 mm, Bureau of Meterology 2012). The vegetation type is temperate woodland (sensu Hobbs \& Yates 2000), dominated by the endangered ecological vegetation community - White box (Eucalyptus albens), Yellow box (Eucalyptus melliodora), Blakely's red gum (Eucalyptus blakelyi) woodland (www. environment.gov.au 2012).

Granitoid formations associated with the Southern Highlands Fold Belt (Wagga Metamorphic Belt) are one of the main lithologies in the SWS (Packham \& Day 1969). Soils derived from surface weathering of granite produces a shallow layer of sandy loam that overlays sandy clay (Norris \& Thomas 1991). Four geomorphologically distinct granite landforms (sensu Campbell 1997; see Michael et al. 2008 for images) occur in the region. These are:

(1) Bornhardt / Dome (6 outcrops) - large, steep-sided dome-shaped hills arising abruptly from the surrounding landscape characterized by large expanses of bare rock. Shallow and elliptical bornhardts are called 'whalebacks' or 'turtlebacks'.

(2) Nubbin (13 outcrops) - small, conical hills rising gently from the surrounding landscape, characterized by small boulder-strewn rock piles.

(3) Castle koppie (8 outcrops) - small, steep-sided hills arising abruptly from the surrounding landscape characterized by large orthogonally fractured boulder stacks.

(4) Tors (17 outcrops) - sparsely aggregated rocks in flat or gently undulating landscapes characterized by individual, block-shaped pillars of various sizes.

\section{Sampling protocol}

Between October 2006 and February 2007, one of the authors (DM) assessed vegetation on 44 privately owned granite outcrops located within agricultural landscapes. Subsets of all four landforms were surveyed each month over the assessment period. With the exception of three outcrops where livestock had been excluded prior to the study, grazing pressure included set stocking rates $(\mathrm{N}=25$ outcrops) or rotational grazing regimes ( $\mathrm{N}=16$ outcrops). On each outcrop, we established a 1 hectare (100 m x 100 
Table 1. Summary of geological and floristic attributes for each granite landform in the SWS bioregion (Bold numbers indicate relatively high or low attribute values).

$\begin{array}{lllll} & \text { Nubbin } & \text { Koppie } & \text { Tor } & \text { Bornhardt } \\ \text { Geomorphological attributes } & & & & \\ \text { Number surveyed } & 13 & 8 & 17 & 6 \\ \text { Mean outcrop size (ha) } & 4.9 & 4.2 & 3.2 & \mathbf{5 7 . 1} \\ \text { Median outcrop size (ha) } & 4 & 5 & 1.5 & \mathbf{1 7 . 5} \\ \text { Exposed rock cover (\%) } & 45 & 55 & 31 & 50 \\ \text { Vegetation structural attributes } & & & \\ \text { Total stem density (stems/ha) } & 54.4 & 42.5 & \mathbf{1 0 . 4} & 60.3 \\ \text { Density of regrowth (DBH }<20 \mathrm{~cm}) & 28.1 & 24.6 & \mathbf{2 . 3} & 30.5 \\ \text { Density of oldgrowth (DBH }>60 \mathrm{~cm}) & 2.4 & 3.4 & 3.5 & 2.4 \\ \text { Native overstorey cover }(\%) & 19 & 17 & \mathbf{5} & 28 \\ \text { Native shrub cover }(\%) & 31 & 13 & \mathbf{1} & 0.8 \\ \text { Total grass cover }(\%) & 28 & 23 & \mathbf{4 8} & 28 \\ \text { Floristics } & & & & \\ \text { Mean native species richness } & 18 & 18 & 12 & 14 \\ \text { Mean exotic species richness } & 9 & 12 & 11 & 8\end{array}$

m) grid and recorded plant species richness over a two hour period by assessing areas with soil, rock crevices and ledges. The average amount of exposed rock within each quadrat ranged from $30 \%$ on tors to $60 \%$ on koppies. In addition, we recorded structural attributes such as overstorey density (live and dead), overstorey stem diameter size class $(0-20 \mathrm{~cm}, 21$ $-40 \mathrm{~cm}, 41-60 \mathrm{~cm}$ and $>60 \mathrm{~cm})$, midstorey height class $(0$ $-0.5 \mathrm{~m}, 0.51-1.0 \mathrm{~m}, 1.1-2.0 \mathrm{~m}$ and $>2 \mathrm{~m})$, percent cover estimates for individual species (overstorey, midstorey and understorey shrubs), percent cover estimates for native and exotic grass cover, native and exotic forbs, woody weeds, rock cover, leaf litter and bare ground. We also recorded the number of logs, stumps and fallen trees in our 1 ha plots. We identified species using Harden (1990 -2002) and followed the nomenclature of PlantNET ( $\underline{\text { www.Plantnet.com.au }}$ ).
For the outcrops in this study the median patch size was 4 ha $($ mode $=5$ ha, mean $=11$ ha, range $0.5-201$ ha) which meant in many cases our sampling area covered a large proportion of the outcrop. We assigned each outcrop a structural complexity score ranging from $1-5$ based on the tally of rocks in six volumetric categories (flat expanses of rock, rocks $<0.5 \mathrm{~m}^{3}$; boulders between $0.5 \mathrm{~m}^{3}-2 \mathrm{~m}^{3}$, pillars between $2 \mathrm{~m}^{3}-5 \mathrm{~m}^{3}$, blocks between $5 \mathrm{~m}^{3}-10 \mathrm{~m}^{3}$; and domes $>10 \mathrm{~m}^{3}$, see Michael et al. 2008).

\section{Statistical analysis}

We completed non-parametric data analysis using options available in Excel, SPSS v7 and Primer v6 (Clarke \& Gorley 2006). We standardized our data to site level and compared species richness, structural attributes and cover

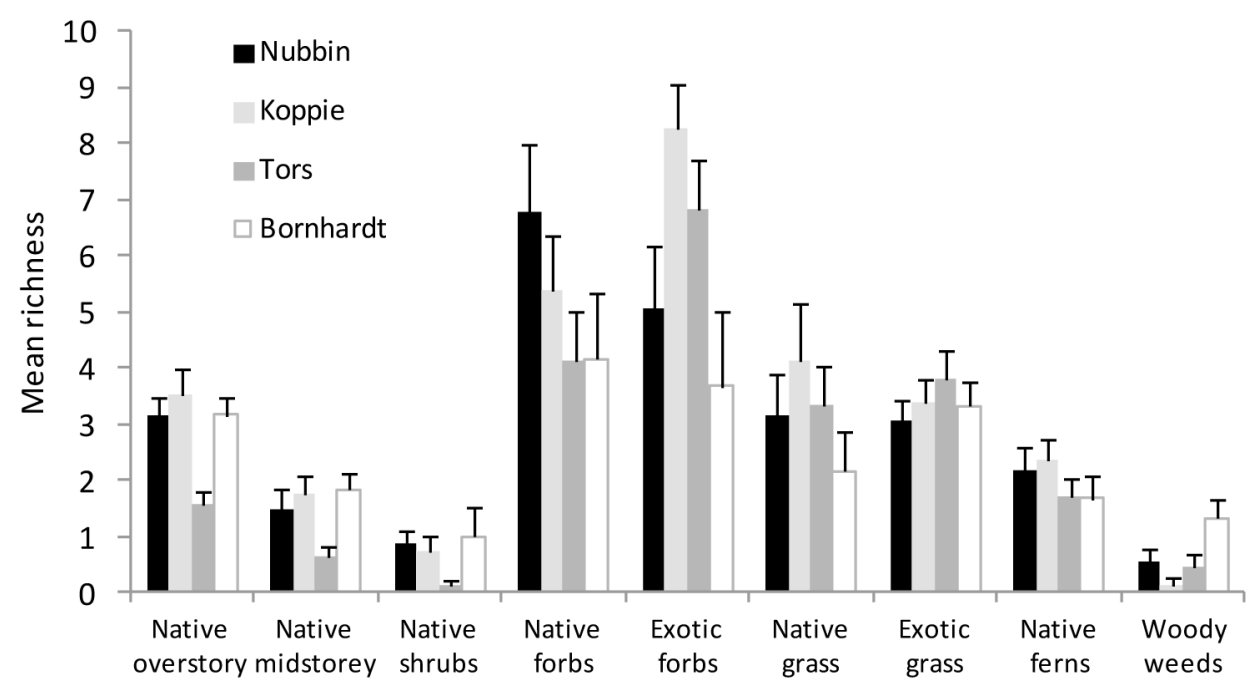

Fig. 1. Variation in mean species richness $( \pm 1 \mathrm{SE})$ for nine floristic groups on four granite landforms in the NSW South-west Slopes. 
abundance estimates among landforms using ANOVA. We used presence/absence data to construct a similarity matrix for all species, native and exotic taxa, and compared floristic composition among landforms (ANOSIM), with 9999 random permutations of the data. We used the Jaccard coefficient of similarity to perform hierarchical cluster analysis (Clarke \& Gorley 2006).

\section{Results}

We recorded a total of 196 vascular plant species (117 native and 79 exotic species) including eight Eucalyptus species, six Acacia species, 45 native forbs, 20 native grasses, 21 exotic grasses, 47 exotic forbs / broad-leaved weeds, and 11 woody weeds (Appendix 1). The dominant families Poaceae and Asteraceae accounted for $36 \%$ of all species. Common overstorey species included Eucalyptus albens (55\% of sites), Acacia implexa (57\%), Eucalyptus blakelyi (50\%) and Brachychiton populneus (48\%). Indigofera australis was the most common shrub (16\%). The most common ground cover species included Isotoma axillaris $(75 \%)$, *Acetosella vulgaris (62\%), *Hordeum leporinum (61\%), Cheilanthes austrotenuifolia (61\%), *Bromus diandrus (55\%), Oxalis perennans (55\%), *Echium plantagineum (52\%), Pleurosurus rutifolius (48\%), Austrodanthonia caespitosa $(48 \%)$, *Avena fatua (46\%), *Hypochaeris radicata $(43 \%)$, *Vulpia myuros (39\%) and Bothriochloa macra (39\%). One threatened species, Senecio garlandii was recorded on two sites. (* above indicates exotic species).

\section{Species richness}

We found that plant species richness did not differ significantly among landforms (F 3, $40=0.8, \mathrm{P}=0.49$ ) and ranged from 22 species on bornhardts to 30 species on

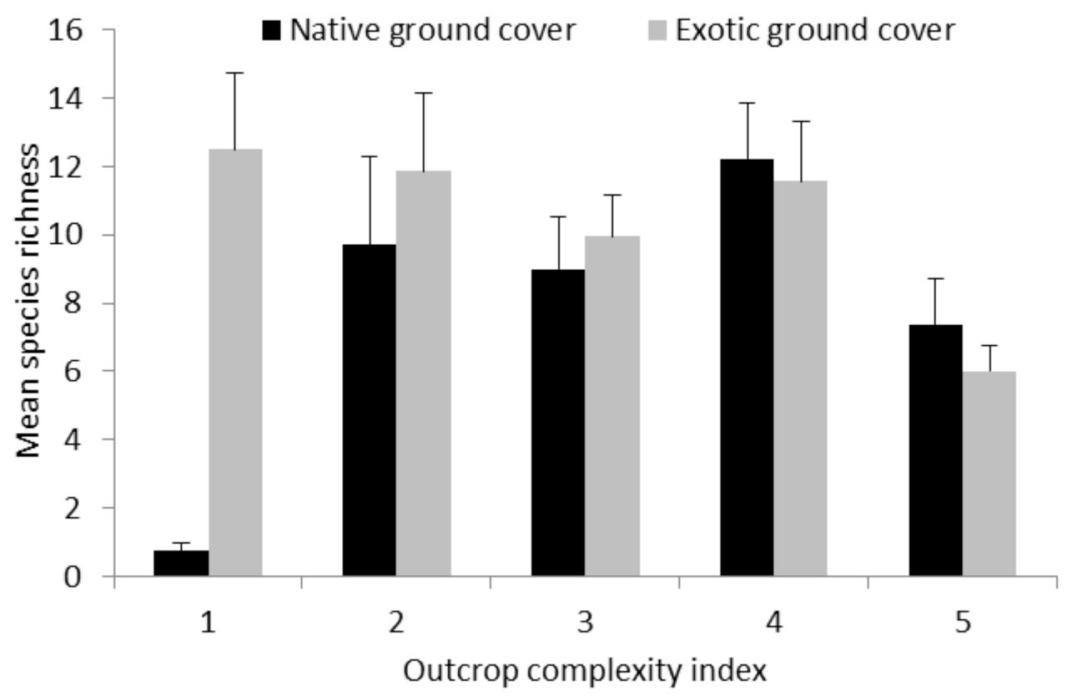

Fig. 2. Variation in mean richness of native and exotic ground cover species $( \pm 1 \mathrm{SE})$ among granite outcrops of varying structural complexity in the NSW South-west Slopes.
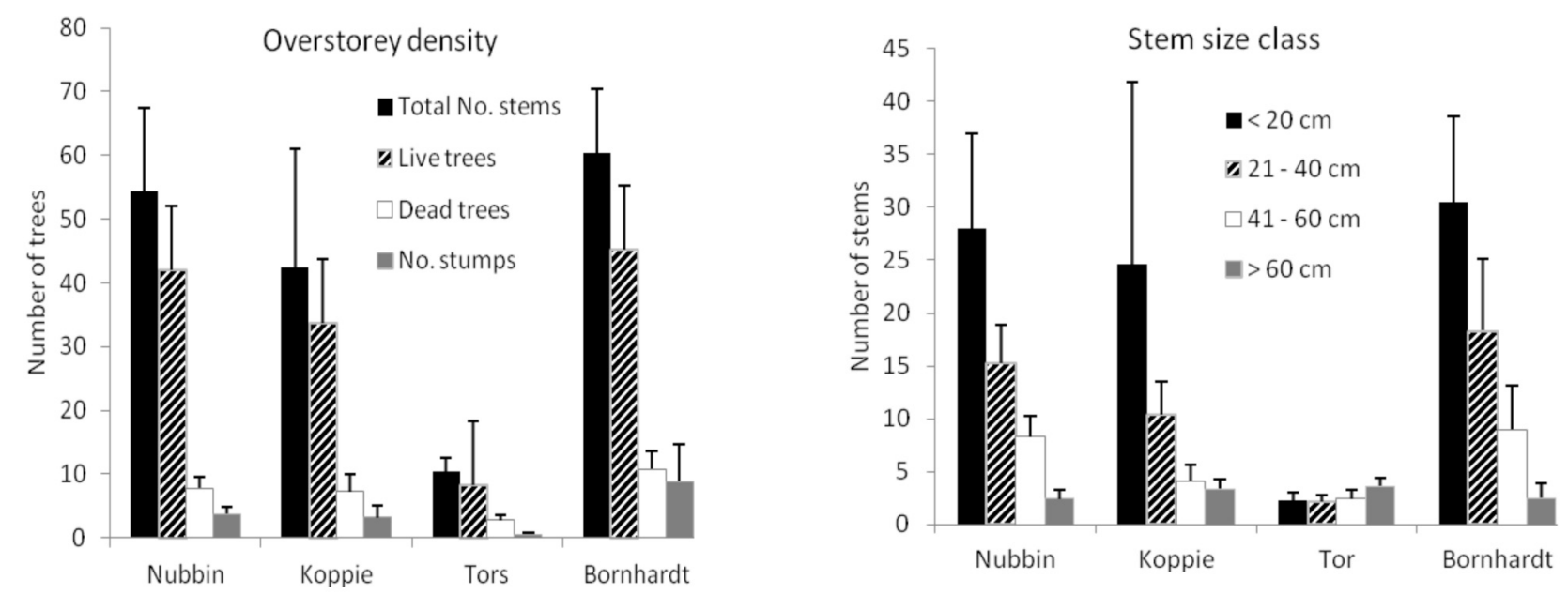

Fig. 3. Variation in the mean density ( $\pm 1 \mathrm{SE})$ of overstorey attributes among granite landforms in the NSW South-west Slopes. 

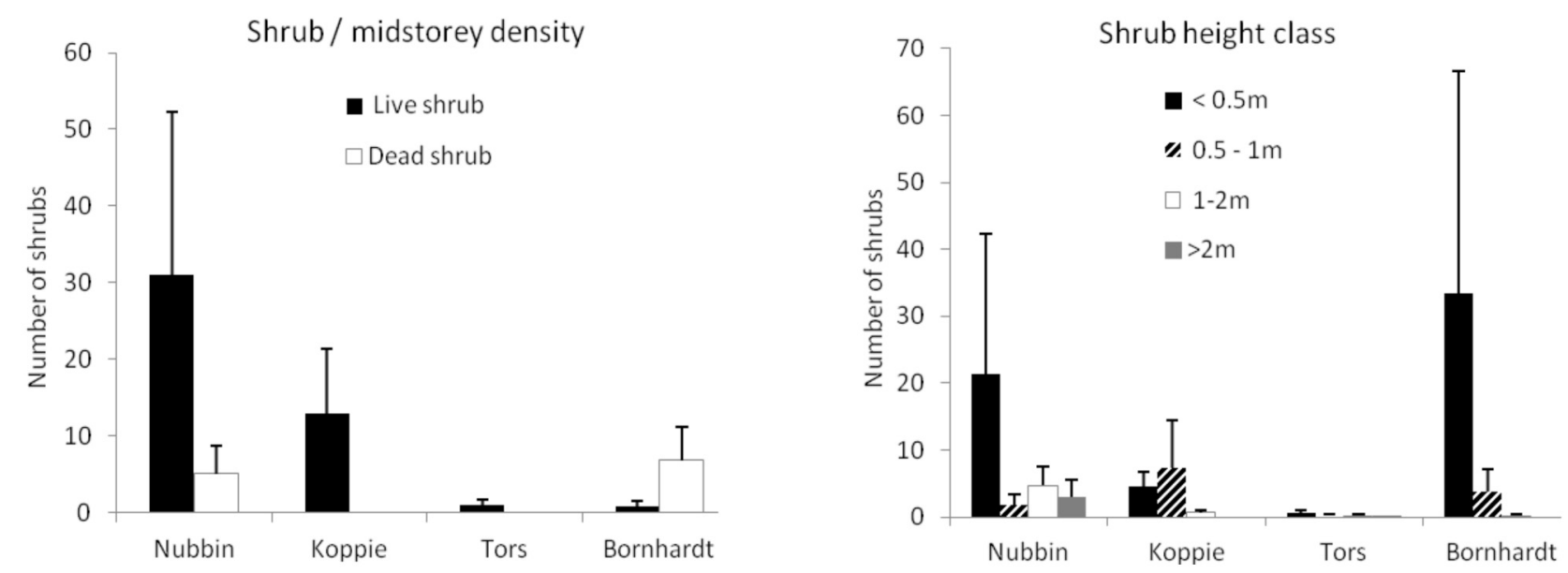

Fig. 4. Variation in the mean density ( $\pm 1 \mathrm{SE})$ of midstorey attributes among granite landforms in the NSW South-west Slopes.

koppies (Table 1). Of floristic groups, native overstorey (F 3, $40=8.89, \mathrm{P}<0.001)$, midstorey $(\mathrm{F} 3,40=3.47, \mathrm{P}=0.02)$ and native shrub species richness $(\mathrm{F} 3,40=3.11, \mathrm{P}=0.03)$ differed significantly among landforms, with tors supporting the least number of species in all three groups (Figure 1). The number of exotic forbs and woody weeds also varied among landforms (Figure 1), although these differences were not significant (exotic forbs F $3,40=2.5, \mathrm{P}=0.07$, woody weeds F $3,40=2.71, \mathrm{P}=0.057$ ).

\section{Relationship between outcrop complexity and species richness}

We found a significant positive linear relationship between native ground cover species richness and outcrop structural complexity $\left(\mathrm{R}^{2}=0.3\right)$, where native species richness increased as a function of complexity. On average, structurally simple outcrops supported one or less native species, whereas complex outcrops supported more than 12 native species (Figure 2). In contrast, we found a strong negative linear relationship between exotic ground cover species richness and outcrop structural complexity $\left(\mathrm{R}^{2}=\right.$ $0.6)$, where exotic species richness decreased as a function of outcrop complexity. On average, structurally simple outcrops supported more than 12 exotic species, whereas, complex outcrops supported half that number (Figure 2).

\section{Vegetation structure}

We found a significant difference in several overstorey attributes among landforms, including total number of stems (F test 3, $40=5.19, \mathrm{P}=0.004)$, number of live trees ( $\mathrm{F}$ test $3,40=4.26, \mathrm{P}=0.01)$, number of dead trees ( $\mathrm{F}$ test $3,40=$ $3.70, \mathrm{P}=0.02)$, and number of tree stumps $(\mathrm{F} 3,40=2.92$, $\mathrm{P}=0.04)$. These results were influenced by tor landforms supporting the lowest value for all four variables mentioned

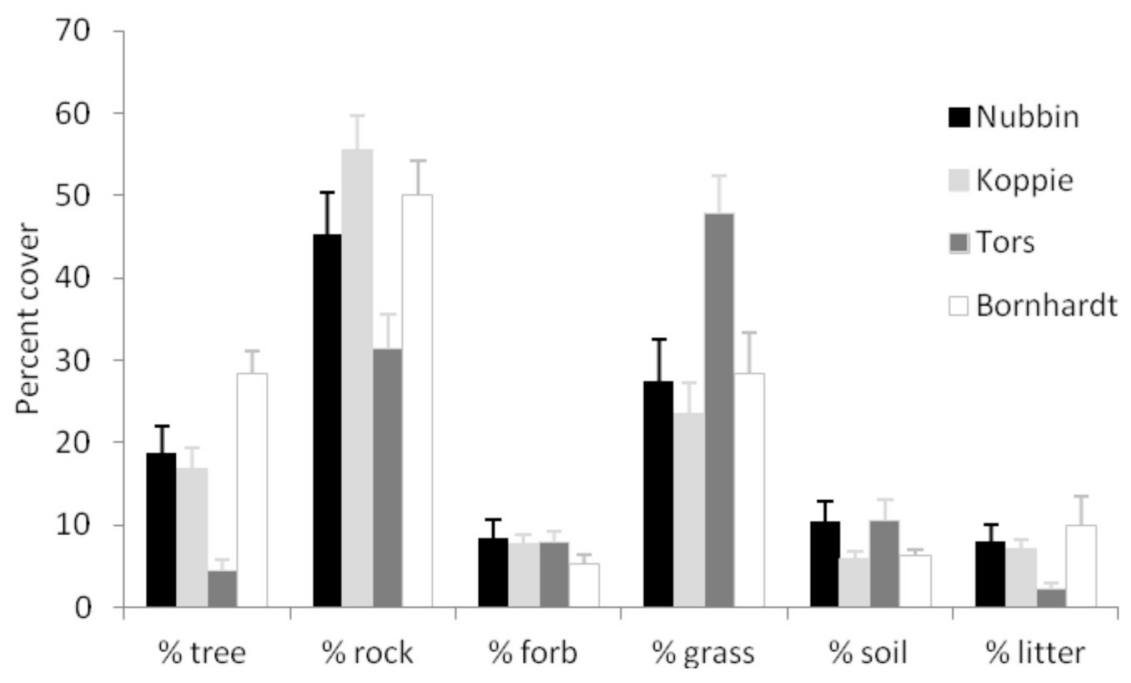

Fig. 5. Variation in percent cover abundance estimates $( \pm 1 \mathrm{SE})$ for biotic and abiotic variables among granite landforms in the South-west Slopes of New South Wales. 
above (Figure 3). The mean number of stems in several diameter size classes also differed significantly among landforms, particularly for number of stems less than $20 \mathrm{~cm}$ (F 3, 40 = 2.88, P = 0.04), between 21 and $40 \mathrm{~cm}(\mathrm{~F} \mathrm{3,} 40=$ $6.24, \mathrm{P}<0.001)$ and between 41 and $60(\mathrm{~F} \mathrm{3}, 40=3.27, \mathrm{P}=$ $0.003)$. These differences were attributed to the low number of stems in all size classes on tor landforms (Figure 3).

We found the mean total number of shrub and midstorey plants did not differ significantly among landforms, although both nubbins and koppies supported an average density of 31 and 13 midstorey plants respectively (nubbin range $=0-271$ plants / ha, koppie range $=0-69$ plants / ha) (Figure 4). In addition, the number of shrub and midstorey plants in four height classes did not differ significantly among landforms (Figure 4).

We found a significant difference in mean percent cover abundance estimates between landforms (Figure 5). These included overstorey tree cover $(\mathrm{F} 3,40=13.72, \mathrm{P}<0.001)$ which was highest on bornhardts and lowest on tors, grass cover $(\mathrm{F} 3,40=5.67, \mathrm{P}=0.002)$ which was highest on tors, and leaf litter cover (F 3, 40 = 3.25, P 0.03) which was lowest on tors.

\section{Floristic composition}

Analysis of similarity (ANOSIM) revealed floristic composition varied significantly among landforms when all species were included (Global R statistic $=0.13, P=1 \%$ ), and for exotic species (Global R statistic $=0.14, P=3 \%$ ), but not for native species (Global R statistic $=0.04, P=$ $21 \%$ ) or just native perennials (Global R statistic $=0.02, P$ $=33 \%$ ). When all species were included, hierarchical cluster analysis revealed high levels of floristic dissimilarity among outcrops, with the majority of outcrops sharing less than $30 \%$ of total species. When exotic species were excluded, cluster analysis showed the majority of outcrops shared less than $40 \%$ of species, and when only native perennials were included, cluster analysis showed the majority of outcrops shared less than $45 \%$ of species (Figure 6 ).

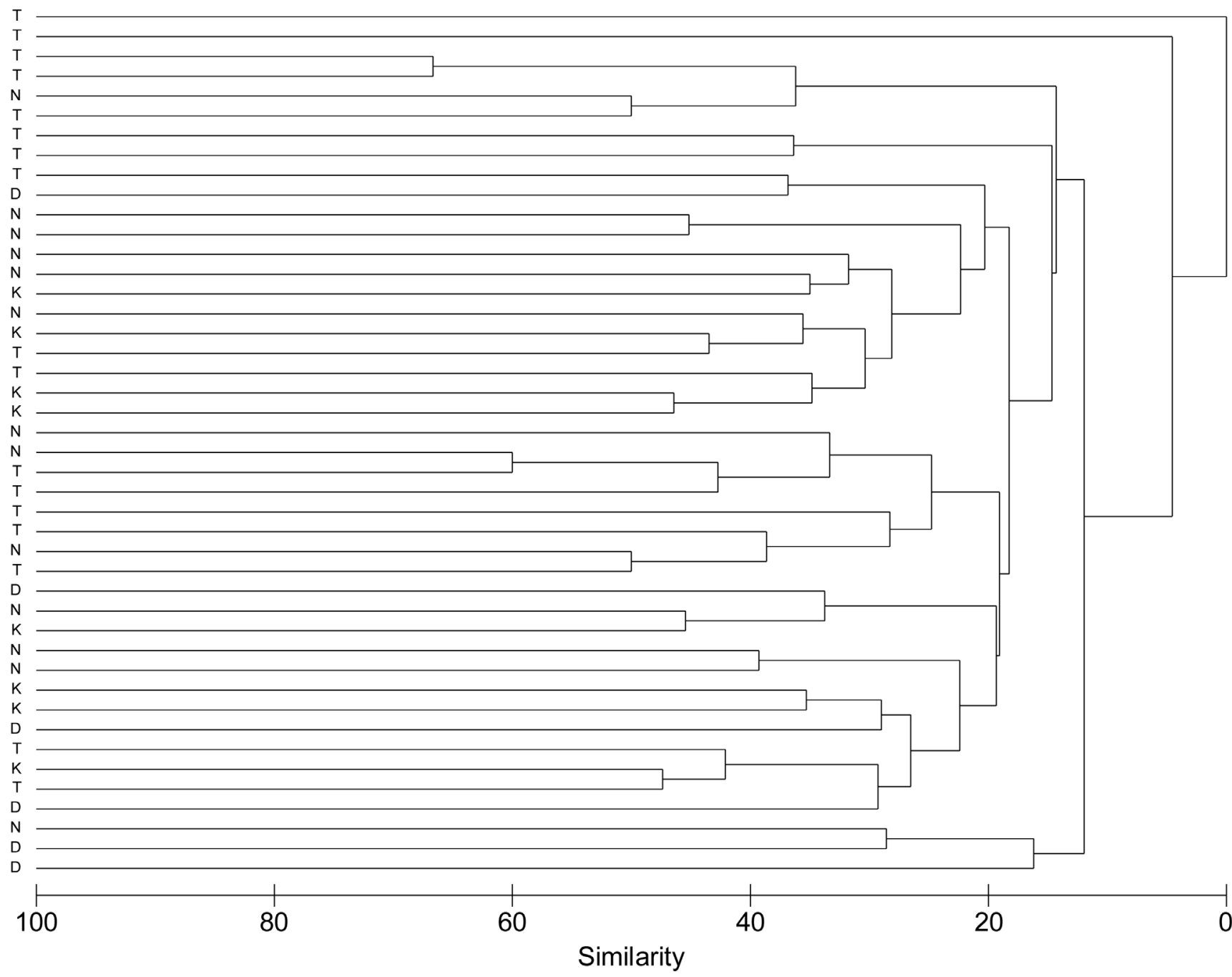

Fig. 6. Heirarchical cluster analysis showing community similarity for native perennial species (Jaccard similarity co-efficient) among outcrops classified by geomorphology in the South-west Slopes of New South Wales $(\mathrm{N}=$ nubbin, $\mathrm{K}=$ koppie, $\mathrm{T}=$ tor, and $\mathrm{D}=\mathrm{Dome} /$ bornhardt). 


\section{Discussion}

Granite inselbergs represent unique environments for plant survival and are typically rich in floristic diversity and endemic taxa (Hopper et al. 1997, Hunter \& Clarke 1998), but there are few studies on small granite outcrops in southeastern Australia (see Norris \& Thomas 1991). This study was conducted during the spring and summer months of a prolonged period of drought, thereby spanning a non-optimal survey period for detecting native annual plant species (Burrows 2004). Nevertheless, we recorded 197 species (Appendix 1), including a new record with approximately 50 individuals of the daisy Senecio garlandii (Asteraceae family), a threatened species listed as Vulnerable under the NSW Threatened Species Conservation Act 1995. Senecio garlandii is currently known from nine locations in the SWS (Burrows 2001). Senecio garlandii (Asteraceae) was recorded growing near the base of outcrops $6.8 \mathrm{~km}$ west of Gerogery and near Big Springs (19 km south of Wagga Wagga). Several regionally significant species were recorded. Correa glabra (Rutaceae) was recorded from the summit of Mount Budginni near the locality of Tabletop, $8 \mathrm{~km}$ north of Albury CBD. Pultenaea platyphylla (Fabaceae) was recorded from rock crevices on two outcrops $13 \mathrm{~km}$ west of Gerogery. Acacia penninervis (Mimosaceae) was recorded growing on the summit of Mount Mullemba ( $8.4 \mathrm{~km}$ north of Walbundrie) and an outcrop near Big Springs (27 km south of Wagga Wagga) and Santalum apiculatum (Santalaceae) was recorded on an outcrop $10 \mathrm{~km}$ east of Henty and $9.4 \mathrm{~km}$ south of Walla Walla.

Additional key findings include: 1) marked differences in mid and overstorey species richness, vegetation structure and floristic composition among granite landforms; 2) multi-directional relationships between the ratio of native and exotic groundcover species and outcrop structural complexity, and 3) high levels of floristic dissimilarity among outcrops. However, because some of our surveys were conducted during less optimal periods of the year for detecting annual forb and grass species in the SWS (Burrows 2004), our results should be interpreted with caution. We discuss the management implications of our findings below and conclude with recommendations to help guide future restoration programs in the SWS bioregion.

\section{Species richness and vegetation structure}

Inherent differences in physical complexity among landforms mean outcrops are differentially affected by agricultural practices. The majority of outcrops in the study region supported remnants of the endangered ecological vegetation community; white box Eucalyptus albens, yellow box Eucalyptus melliodora, Blakely's red gum Eucalyptus blakelyi woodland, although species richness, vegetation cover and condition varied among landforms. In general, tor landforms were dominated by exotic grasses and forbs (Figure 1), lacked shrubs (Figure 4) and supported less than $5 \%$ tree cover (Figure 5). By contrast, complex outcrops supported greater plant diversity (Figure 2), multiple strata, and more vegetation cover (Figure 5). Tor landforms are the highly eroded remnants of bornhardts and consequently occur in relatively flat, productive landscapes (Twidale 1982). Historically, native vegetation growing on the most productive soils has been extensively cleared for agriculture, whereas native vegetation growing on poorer soils has often survived relatively intact, but exposed to disturbances such as fire, logging and livestock grazing (Prober \& Thiele 2004). Fire can cause Eucalyptus species to resprout from basal lignotubers (Gill 1981, Noble 2001), whereas logging activities often leave behind cut stumps which resprout above the ground (Figure 7) (Wildy et al. 2000). Both regeneration pathways can produce cohorts of multi-stemmed trees. The high density of small-sized overstorey stems (less than 20 $\mathrm{cm}$ ) and tree stumps on nubbins and koppies (Table 1) is indicative of previous fire and logging activities.

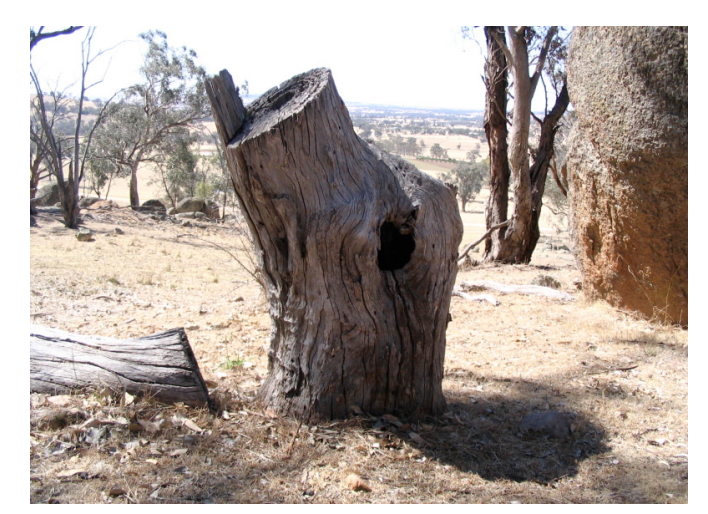

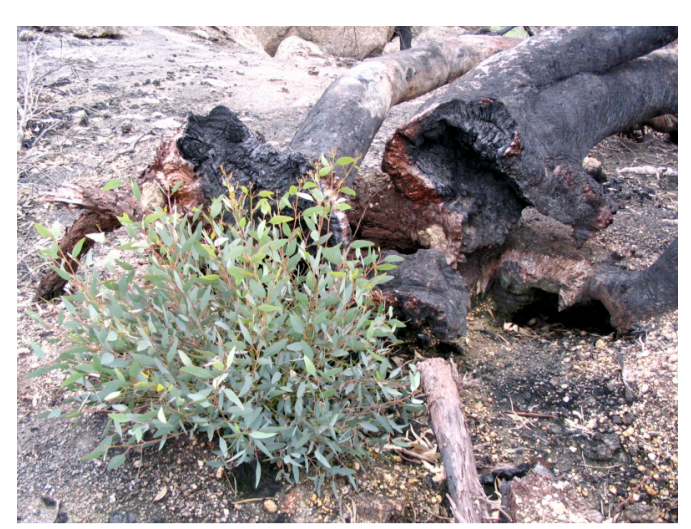




\section{Environmental and agricultural weeds}

Exotic plants have become naturalized on granite outcrops around the world and are considered a major problem in preserving the integrity of inselberg flora (Porembski 2000). Exotic species can alter vegetation structure and fire regimes (Benwell 2007) and cause the extinction of endemic taxa (Pigott 2000). In this study $40 \%$ of the plants recorded were exotic, mostly agricultural species from the Poaceae and Asteraceae families (Appendix 1). However, had we conducted multiple surveys during different times of the year, the actual number of exotic species is predicted to be higher (Burrows 1999).

An interesting outcome of this study was the relationship between outcrop physical complexity, and a high number of native species but low number of exotic species (Figure 2). Structurally complex outcrops may support more native species because of the greater breadth of microhabitats available serving as refugia from livestock grazing. However, other factors such as fire history and the distance to roads, homesteads and towns, may also influence which invasive plants are likely to be present. Several 'woody weed' species recorded in this study have the potential to cause serious concern because they are long-lived, able to survive harsh conditions, and spread prolifically when mature (Low 1999). These species which include *Ailanthus altissima, *Celtis australis, *Lycium ferocissimum, *Opuntia stricta, *Prunus spp., *Robinia pseudoacacia and *Schinus areira can be controlled and should be managed before they become a costly environmental problem. Several native species not local to the SWS including Melia azedarach were also recorded.

\section{Floristic composition}

A key finding of this study was that floristic composition between outcrops was significantly dissimilar, with the majority of outcrops sharing less than $30 \%$ of total species, and less than $40 \%$ of native species (Figure 6). This result appears to be characteristic of granite outcrops in general. For example, Norris \& Thomas (1991) found several granite outcrops in the SWS were floristically dissimilar. Furthermore, patterns of floristic diversity on granite outcrops in Western Australia are characterized by high diversity within homogenous habitats ( $\alpha$-diversity), high species turnover along environmental gradients ( $\beta$-diversity) and high species turnover among similar habitats across geographical gradients ( $\gamma$-diversity) (Hopper 1992, Hopper et al. 1996). Our findings suggests that small granite outcrops in modified landscapes also conform to general patterns of floristic diversity, and highlights the need to protect a broad range of outcrops to maintain floristic diversity on a regional scale, by fencing out livestock and controlling feral animals such as goats, deer and rabbits.

\section{Management Implications}

Traditional revegetation programs focus on stabilizing creek banks, mitigating dry land salinity by planting hill tops, creating wind breaks for livestock, and establishing wildlife corridors (Munroe \& Lindenmayer 2011). In most cases, these efforts fail to incorporate rocky outcrops and consequently, many outcrops remain devoid of overstorey vegetation. In the SWS, many outcrops are less than 10 ha in size and occur as habitat isolates embedded within highly modified, cleared landscapes. This enhanced insularity has implications for the long-term persistence of saxicolous plant populations, especially for species with few individuals and which do not occur on the intervening parts of the landscape (Broadhurst \& Young 2006). Our study has identified tor landforms to be severely degraded and in immediate need of restoration. Broadhurst et al. (2008) suggest introducing germplasm from genetically diverse source populations is required to increase the long-term viability of small plant populations in fragmented landscapes. This principle is applicable to outcrops in the SWS as they support small populations of several shrub species and small trees (Appendix 1). However ecological constrains such as grazing may be limiting some species, and landforms which support moderate amounts of remnant vegetation, such as koppies and nubbins, may benefit most from fencing to keep out livestock and feral herbivores, and to encourage natural regeneration.

Two findings of this study relevant to the design of restoration programs were the presence of shrubs and small trees, and the low density of large mature trees on structurally complex outcrops. The composition and structure of woodland vegetation may have important implications for the survival of rock-dwelling taxa. A recent study in the SWS bioregion for example found high densities of overstorey regrowth vegetation produced high shade levels and supported lower reptile diversity than structurally open outcrops (Michael et al. 2008). Dense vegetative regrowth may also affect growing conditions for saxicolous plants by competing for light and space, and altering micro-climatic conditions (Benwell 2007). Choosing appropriate plant species and carefully considering the density and spatial arrangement of plantings are fundamental issues in the design of future restoration programs involving outcrops.

\section{Conclusion}

We examined vegetation structure and floristic composition of relatively small $(<11$ ha) granite outcrops in modified landscapes. Tor landforms were most degraded and were characterized by a significant absence of canopy cover, midstorey species, shrubs and native ground cover. Tor landforms could therefore provide nodal points in the design of future restoration activities, which will need to consider appropriate plant species, the spatial arrangement of plantings and genetic diversity of seed stock. Overall, the high percentage of floristic dissimilarity among outcrops in this study highlights the need to manage a broad spectrum of outcrops to maintain floristic diversity in the SWS bioregion. In many cases, this may only require fencing out livestock, controlling invasive plants, monitoring outcomes and adjusting management according to site-specific objectives. 


\section{Acknowledgements}

The authors thank the landholders who granted us permission to work on their property, in particular Chris and Sue Cain, Alan Scammel, Trish Esla, John Delaney, Paul Jaris, Rosellyn McClellan, Dick Hall, Chris Donovan, Russel Paech, Isabel and Peter Webb, Doogle McKay, Robert O'Brian, David Pugh, Frank Forrigan, Pat Wilson, Frank Palmer, Frank Chambers, Krissy Campbell, Charles Packer, Eddy Wright and Peter Wallis. Thanks to Ian Lunt and Wayne Robinson for thoughtful discussions on the topic and advice on this manuscript.

\section{References}

Ashton, D.H. \& Webb, R.N. (1977) The ecology of granite outcrops at Wilson's Promontory, Victoria. Australian Journal of Ecology 2: 269-296.

Beadle, N.C.W. (1981) The vegetation of Australia. (Cambridge University Press: New York).

Benson, J.S. (2008) New South Wales vegetation classification and assessment: part 2 plant communities of the NSW Southwestern Slopes bioregion and update of the NSW Western Plains plant communities, version 2 of the NSWVCA database. Cunninghamia 10: 599-673.

Benwell, A. (2007) Response of rock-outcrop and fringing vegetation to disturbance by fire and drought. Australian Journal of Botany 55: 736-748.

Bradstock R.A., Williams J.E. and Gill M. (2002) Flammable Australia: The fire regimes and biodiversity of a continent. (Cambridge University Press: UK).

Broadhurst, L.M. and Young, A.G. (2006) Reproductive constraints for the long-term persistence of fragmented Acacia dealbata (Mimosaceae) populations in southeast Australia. Biological Conservation 133: 512-526.

Broadhurst, L.M., Young, A.G. and Forrester, R. (2008) Genetic and demographic responses of fragmented Acacia dealbata (Mimosaceae) populations in southeast Australia. Biological Conservation 141: 2843-2856.

Burgman, M.A. (1987) An analysis of the distribution of plants on granite outcrops in southern-western Australia using Mantel tests. Vegetatio 71: 79-86.

Burke, A. (2003) Inselbergs in a changing world - global trends. Diversity and Distributions 9: 375-383.

Burrows, G. (1999) A survey of 25 remnant vegetation sites in the South Western Slopes, New South Wales. Cunninghamia 6(2): 283-299.

Burrows, G. (2001) An assessment of the conservation status of Senecio garlandii, in the Central and South Western Slopes, New South Wales. Cunninghamia 7(1): 65-76.

Burrows, G. (2004) The importance of seasonality in the timing of flora surveys in the South and Central Western Slopes of New South Wales. Cunninghamia 8(4): 514-520.

Butler, D.W. \& Fensham, R.J. (2008) Lose the plot: cost-effective survey of the Peak Range, central Queensland. Cunninghamia 10: $521-538$.

Campbell, E.M. (1997) Granite landforms. Journal of the Royal Society of Western Australia 80: 101-112.

Clarke P.J. (2002) Habitat islands in fire-prone vegetation: do landscape features influence community composition? Journal of Biogeography 29: 1-8.

Clarke K.R. \& Gorley R.N. (2006) PRIMER v6 (Plymouth Marine Laboratory).
Gill, A.M. (1981) Adaptive responses of Australian vascular plant species to fires. In: Gill. A.M., Groves, R.H. \& Noble, I.R. (eds) Fire and the Australian biota, pp 243-271 (National Academy of Science: Canberra).

Harden, G.J. (1990 - 2002) Flora of New South Wales. Vols I-IV (University of New South Wales Press: Sydney).

Hobbs, R.J. \& Yates, C.J. (2000) Temperate eucalypt woodlands in Australia. (Surrey Beatty and Sons, Chipping Norton: Australia).

Hopper , S.D. (1992) Patterns of plant diversity at the population and species levels in south-west Australian Mediterranean ecosystems. In: Hobbs, R.J. (ed) Biodiversity of Mediterranean ecosystems in Australia, pp. 27-46. (Surrey Beatty \& Sons, Chipping Norton: UK).

Hopper, S.D., Harvey, M.S., Chappill, J.A., Main, A.R. \& Main, B.Y. (1996) The Western Australian Biota as Gondwanan heritage - a review. In Hopper, S.D., Chappil, J.A., Harvey, M.S. \& George, A.S. (eds) Gondwanan heritage, pp. 1-46. (Surrey Beatty \& Sons, Chipping Norton: UK).

Hopper, S.D., Brown, A.P. \& Marchant, N.G. (1997) Plants of Western Australian granite outcrops. Journal of the Royal Society of Western Australia 80: 141-158.

Hunter, J.T. and Clarke, P.J. (1998) The vegetation of granitic outcrop communities on the New England Batholith of eastern Australia. Cunninghamia 5: 547-618.

Keith D. A. (1996) Fire-driven extinction of plant populations: a synthesis of theory and review of evidence from Australian vegetation. Proceedings of the Linnean Society of New South Wales 116: 37-78.

Kruckenburg, A.R. (2002) Geology and plant life: The effects of landforms and rock type on plants. (University of Washington Press: USA).

Lindenmayer, D.B., Archer, S., Barton, P., Bond, S., Crane, M., Gibbons, P., Kay, G., MacGregor, C., Manning, A., Michael D.R., Montague-Drake, R., Munroe, N., Muntz, R. and Stagoll, K. (2011) What makes a good farm for wildlife? (CSIRO Publishing, Collingwood: Melbourne).

Low, T. (1999) Feral Future. (Viking: Australia).

Noble J.C. (2001) Lignotubers and meristem dependence in mallee (Eucalyptus spp.) coppicing after fire. Australian Journal of Botany 49: 31-41.

Michael, D.R., Cunningham, R.B. \& Lindenmayer, D.B. (2008) A forgotten habitat? Granite inselbergs conserve reptile diversity in fragmented agricultural landscapes in south-eastern Australia. Journal of Applied Ecology 45: 1742-52.

Michael, D.R., Cunningham, R.B. \& Lindenmayer, D.B. (2010a) Microhabitat relationships among five lizard species associated with granite outcrops in fragmented agricultural landscapes of South-eastern Australia. Austral Ecology 35: 214-225

Michael, D.R., Lindenmayer, D.B. \& Cunningham, R.B. (2010b) Managing rock outcrops to improve biodiversity conservation in Australian agricultural landscapes. Ecological Management and Restoration 11: 43-50.

Munroe, N. \& Lindenmayer, D.B. (2011) Planting for wildlife: A practical guide to restoring native woodlands. (CSIRO Publishing, Collingwood: Melbourne).

Murray Catchment Management Authority (2011) Murray Catchment Management Authority Incentive Funding Program (Murray Catchment Management Authority: Albury).

Norris, E.H. \& Thomas, J. (1991) Vegetation on rocky outcrops and ranges in central and south-western New South Wales. Cunninghamia 2: 411-441.

Ohlemuller, R. (1997) Biodiversity patterns of plant communities in shallow depressions on Western Australian granite outcrops (inselbergs) (Diplomarbeit zur Erlangung des Grades eines Diplom-Biologen, University of Bonn: Bonn). 
Ornduff, R. (1987) Islands on islands: plant life on the granite outcrops of Western Australia (University of Hawaii Press: Honolulu).

Packham G.H. \& Day A.A. (1969) The general features of the geological provinces of

New South Wales. Journal of the Geological Society of Australia 16: $1-17$.

Pigott, J. P. (2000) Environmental weeds and granite outcrops: possible solutions in the "too hard basket"? Journal of the Royal Society of Western Australia 83: 135-137.

Prober, S. (1996) Conservation of the grassy white box woodlands: range wide floristic variation and implications for reserve design. Australian Journal of Botany 44: 57-77.

Porembski, S. (2000) The invasibility of tropical granite outcrops ('inselbergs') by exotic weeds. Journal of the Royal Society of Western Australia 83: 131-137.

Porembski, S. \& Barthlott, W. (2000) Inselbergs: biotic diversity of isolated rock outcrops in tropical and temperate regions (Ecological Studies 146, Springer-Verlag: Berlin).
Porembski, S., Seine, R. and Barthlott, W. (1997) Inselberg vegetation and the biodiversity of granite outcrops. Journal of the Royal Society of Western Australia 80: 193-199.

Smith, G.G. (1961) The flora of granite rocks of the Poronturup Range, south-western Australia. Journal of the Royal Society of Western Australia 45: 18-23.

Twidale, C.R. (1982) Granite landforms (Elsevier: Amsterdam).

Walters, T.W. (1982) The vascular flora of granite outcrops in the Central Mineral Region of Texas. Bulletin of the Torrey Botanical Club 109: 344-364.

Wildy, D.T., Bartle, J.R., Pate, J.S., Arthur, D.J. (2000) Sapling and coppice biomass production by alley-farmed 'oil mallee' Eucalyptus species in the Western Australian wheatbelt. Australian Forestry 63: 147-157.

Yates, C. \& Hobbs, R. (1997) Temperate eucalypt woodlands: a review of their status, processes threatening their persistence and techniques for restoration. Australian Journal of Botany 45: 949-973.

Manuscript accepted 14 August 2012

\section{Appendix 1. Native and exotic plant species recorded on four granite landforms in the South-west Slopes of NSW between October 2006 and February 2007 showing percentage frequency on each landform.}

* = introduced species, $\#=$ noxious species, $+=$ species listed in the NSW Threatened Species Conservation Act 1995).

\section{No of sites}

Nubbin

Koppie

13

8

Tors

Bornhardt

\section{PTERIDOPHYTES}

Adiantaceae

Adiantum aethiopicum

Cheilanthes austrotenuifolia

Cheilanthes distans

Cheilanthes sieberi

Aspleniaceae

Asplenium flabellifolium

Pleurosorus rutifolius

GYMNOSPERMS

Cupressaceae

Callitris endlicheri

Callitris glaucophylla

\section{ANGIOSPERMS}

Amygdalaceae

Prunus dulcis*

Prunus cerasifera*

Anacardiaceae

Schinus areira*

Anthericaceae

Arthropodium minus

Dichopogon fimbriatus

Tricoryne elatior

Apiaceae

Daucus glochidiatus

Hydrocotyle laxiflora

\section{0}

50

0

33

0

67

17

33

$\begin{array}{ll}0 & 0 \\ 6 & 0\end{array}$




\section{Nubbin}

13

No of sites

Asteraceae

Arctotheca calendula*

Bidens pilosa*

Carduus tenuiflorus*

Carthamus lanatus*

Cassinia aculeata

Cassinia laevis

Cassinia longifolia

Centaurea calcitrapa*

Cichorium intybus*

Cirsium vulgare*

Conyza sumatrensis*

Conyza bonariensis*

Cynara cardunculus*\#

Helichrysum rutidolepis

Hypochaeris glabra*

Hypochaeris radicata*

Lactuca serriola*

Onopordum acanthium*

Silybum marianum*

Senecio garlandii+

Senecio hispidulus

Senecio quadritentatus

Sonchus asper*

Sonchus oleraceus*

Taraxacum officinale*

Vittadinia cuneata

Xanthium spinosum*\#

Xerochrysum viscosum

Boraginaceae

Echium plantagineum*

Heliotropium europaeum *

Cactaceae

Opuntia stricta*\#

Campanulaceae

Wahlenbergia communis

Wahlenbergia stricta

Wahlenbergia gracilenta

Caryophyllaceae

Cerastium glomeratum*

Moenchia erecta*

Spergularia rubra*

Stellaria media*

Casuarinaceae

Allocasuarina verticillata

Chenopodiaceae

Dysphania pumilio

Einadia nutans

Convolvulaceae

Convolvulus erubescens

Dichondra repens

Crassulaceae

Crassula decumbens

Cucurbitaceae

Citrullus colocynthis*

Cucumis myriocarpus*

23

0

8

23

8

8

15

8

8

38

0

0

0

0

31

38

0

8

8

0

8

8

0

0

15

15

8

15

23

0

0

0

0

23

0

8

8

15

23

46

0

8

0

15

\section{Koppie}

8

Tors

17

Bornhardt

6

0

25

33

0

13

13

13

13

0

38

13$$
47
$$ 


No of sites
Cyperaceae
Carex appressa
Lepidosperma laterale
Dilleniaceae
Hibbertia obtusifolia
Ericaceae
Brachyloma daphnoides
Lissanthe strigosa
Melichrus urceolatus

$\begin{array}{lll}\text { Nubbin } & \text { Koppie } & \text { Tors }\end{array}$

Fabaceae

Acacia buxifolia

Acacia rubida

Acacia implexa

Acacia genistifolia

Acacia penninervis

Acacia doratoxylon

Desmodium varians

Glycine clandestina

Glycine tabacina

Hardenbergia violacea

Indigofera adesmiifolia

Indigofera australis

Pultenaea cunninghamii

Pultenaea platyphylla

Pultenaea foliolosa

Robinia pseudoacacia*

Trifolium $s p^{*}$

0

0

23

8

23

0

\section{8}

8

54

8

0

15

8

8

15

15

0

23

0

0

8

8

8

Gentianaceae

Centaurium erythraea*

Geraniaceae

Erodium cicutarium*

Geranium retrorsum

Geranium solanderi

Pelagonium australe

Goodeniaceae

Goodenia pinnatifida

Haloragaceae

Gonocarpus elatus

Gonocarpus tetragynus

Hypericaceae

Hypericum perforatum*

Iridaceae

Romulea rosea*

Juncaceae

Juncus filicaulis

Lamiaceae

Ajuga australis Marrubium vulgare* Salvia verbenaca*

Lobeliaceae

Isotoma axillaris

Loranthaceae

Amyema miquelii

Amyema miraculosum

Amyema pendulum

8

8

54

31

31

8

0

0

62
3

25

18

0

0

12

0

0

0

6

0

0

0

0

$13 \quad 0 \quad 0$

$\begin{array}{lll}38 & 12 & 17\end{array}$

$100 \quad 41 \quad 50$

0

13

0

0

25

13

0

13

25

13

13

0

0

38

0

0

0

17

$\begin{array}{cc}24 & 17 \\ 0 & 0\end{array}$

24

12

17

0

0

0

50

50

33

0

0

25

0

$8 \quad 13$

13
25

13

17

0

100

71

83

13

25

13
0

0 


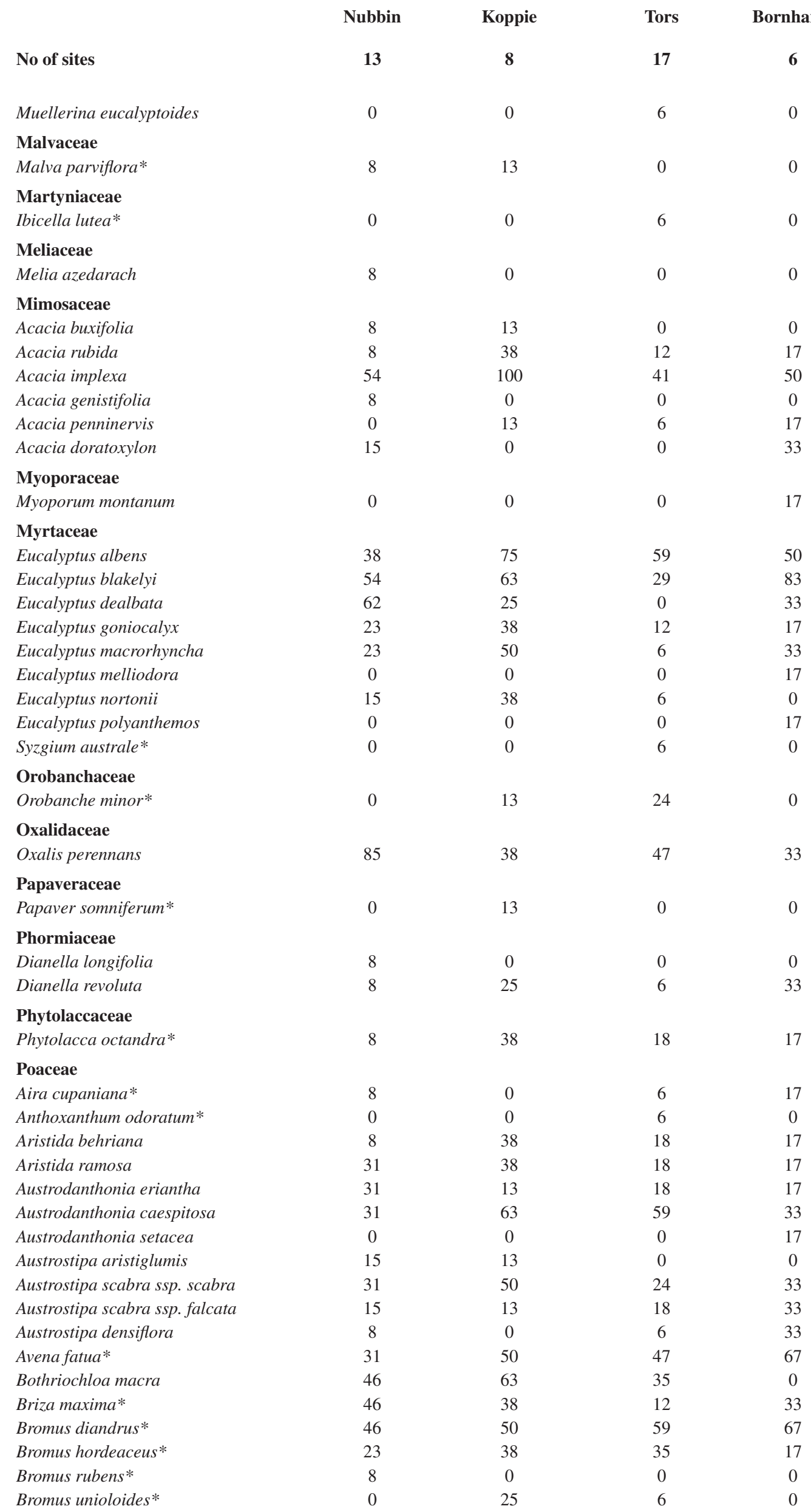




\begin{tabular}{|c|c|c|c|c|}
\hline & Nubbin & Koppie & Tors & Bornhard \\
\hline No of sites & 13 & 8 & 17 & 6 \\
\hline Chloris truncata & 8 & 13 & 6 & 0 \\
\hline Cymbopogon refractus & 8 & 0 & 6 & 0 \\
\hline Cynosurus echinatus* & 8 & 0 & 0 & 0 \\
\hline Cynodon dactylon & 0 & 0 & 6 & 0 \\
\hline Dichelachne crinata & 38 & 38 & 35 & 0 \\
\hline Eleusine tristachya* & 8 & 0 & 0 & 0 \\
\hline Elymus scaber & 15 & 50 & 35 & 17 \\
\hline Holcus lanatus* & 0 & 0 & 6 & 0 \\
\hline Hordeum leporinum* & 62 & 38 & 82 & 33 \\
\hline Hyparrhenia hirta*\# & 0 & 13 & 6 & 0 \\
\hline Joycea pallida & 0 & 0 & 6 & 0 \\
\hline Lamarckia aurea* & 15 & 0 & 0 & 0 \\
\hline Lolium perenne* & 15 & 25 & 24 & 33 \\
\hline Microlaena stipoides & 8 & 0 & 24 & 0 \\
\hline Panicum effusum & 8 & 13 & 12 & 0 \\
\hline Paspalum dialatum* & 8 & 0 & 6 & 17 \\
\hline Phalaris aquatica* & 0 & 13 & 18 & 0 \\
\hline Phalaris paradoxa* & 0 & 0 & 6 & 0 \\
\hline Poa sieberi & 15 & 13 & 6 & 0 \\
\hline Роа аппиа $*$ & 0 & 0 & 6 & 0 \\
\hline Setaria verticillata* & 0 & 0 & 6 & 0 \\
\hline Themeda australis & 0 & 0 & 6 & 0 \\
\hline Vulpia bromoides* & 0 & 13 & 18 & 0 \\
\hline Vulpia myuros* & 38 & 38 & 35 & 50 \\
\hline \multicolumn{5}{|l|}{ Polygonaceae } \\
\hline Acetosella vulgaris* & 46 & 100 & 71 & 17 \\
\hline Rumex brownii & 38 & 38 & 47 & 0 \\
\hline \multicolumn{5}{|l|}{ Portulacaceae } \\
\hline Portulaca oleracea & 0 & 0 & 6 & 0 \\
\hline \multicolumn{5}{|l|}{ Proteaceae } \\
\hline Grevillea floribunda & 0 & 0 & 0 & 17 \\
\hline \multicolumn{5}{|l|}{ Rosaceae } \\
\hline Rosa rubiginosa* & 0 & 0 & 12 & 0 \\
\hline Rubus fruticosus* & 0 & 38 & 12 & 17 \\
\hline \multicolumn{5}{|l|}{ Rubiaceae } \\
\hline Galium aparine* & 0 & 0 & 0 & 17 \\
\hline Galium gaudichaudii & 8 & 0 & 0 & 0 \\
\hline \multicolumn{5}{|l|}{ Rutaceae } \\
\hline Correa glabra & 8 & 0 & 0 & 0 \\
\hline Correa reflexa & 0 & 13 & 0 & 0 \\
\hline \multicolumn{5}{|l|}{ Santalaceae } \\
\hline Exocarpus cupressiformis & 23 & 63 & 0 & 33 \\
\hline Santalum apiculatum & 8 & 13 & 0 & 0 \\
\hline \multicolumn{5}{|l|}{ Sapindaceae } \\
\hline Dodonea viscosa & 8 & 13 & 0 & 17 \\
\hline \multicolumn{5}{|l|}{ Scrophulariaceae } \\
\hline Verbascum virgatum* & 8 & 75 & 29 & 17 \\
\hline \multicolumn{5}{|l|}{ Simaroubaceae } \\
\hline Ailanthus altissima* & 0 & 0 & 18 & 17 \\
\hline \multicolumn{5}{|l|}{ Solanaceae } \\
\hline Lycium ferocissimum* & 8 & 0 & 0 & 17 \\
\hline Solanum cinereum & 0 & 13 & 6 & 0 \\
\hline Solanum elaeagnifolium* & 15 & 0 & 0 & 0 \\
\hline Solanum nigra* & 8 & 38 & 53 & 33 \\
\hline Solanum simile & 0 & 0 & 0 & 17 \\
\hline
\end{tabular}




\begin{tabular}{|c|c|c|c|c|}
\hline & Nubbin & Koppie & Tors & Bornhar \\
\hline No of sites & 13 & 8 & 17 & 6 \\
\hline \multicolumn{5}{|l|}{ Sterculiaceae } \\
\hline Brachychiton populneus & 62 & 63 & 41 & 17 \\
\hline \multicolumn{5}{|l|}{ Thymelaeaceae } \\
\hline Pimelea linifolia & 15 & 13 & 0 & 0 \\
\hline \multicolumn{5}{|l|}{ Ulmaceae } \\
\hline Celtis australis* & 8 & 13 & 0 & 0 \\
\hline \multicolumn{5}{|l|}{ Urticaceae } \\
\hline Urtica urens* & 0 & 13 & 6 & 0 \\
\hline \multicolumn{5}{|l|}{ Viscaceae } \\
\hline Notothixos cornifolius & 0 & 25 & 6 & 0 \\
\hline \multicolumn{5}{|l|}{ Xanthorrhoeaceae } \\
\hline Lomandra filiformis & 23 & 25 & 35 & 0 \\
\hline Lomandra longifolia & 0 & 25 & 6 & 0 \\
\hline Lomandra multiflora & 15 & 13 & 0 & 17 \\
\hline
\end{tabular}

Zygophyllaceae

Tribulus occidentalis 